\title{
KEBERHASILAN PENGUASAAN BAHASA INGGRIS MENURUT GAYA BELAJAR DAN TIPE KEPRIBADIAN PESERTA DIDIK
}

\author{
Operlin Gultom \\ Guru SMAN 3 Tanjung Jabung Barat \\ Email : opgultom112@gmail.com
}

\begin{abstract}
Abstrak
Tulisan ini merupakan penelitian dengan studi literatur dari beberapa jurnal, hasil penelitian dan buku-buku referensi tentang keberhasilan peserta didik dalam menguasai Bahasa Inggris menurut Gaya Belajar ditinjau dari tipe kepribadian peserta didik. Metode yang digunakan adalah studi kepustakaan, dimana penulis mengumpulkan informasi dari penelitian -penelitian yang relevan. Tipe kepribadian peserta didik difokuskan pada tipe Extrovert dan Introvert, sesuai dengan pernyataan Myer and Briggs bahwa tipe Kepribadian Extrovert dan Introvert sangat berpengaruh terhadap keberhasilan peserta didik dalam meningkatkan hasil belajar. Dari buku-buku referensi, didapatkan informasi bahwa gaya belajar tipe kepribadian Extrovert dan Introvert berbeda didalam proses pembelajaran bahasa Asing khususnya Bahasa Inggris. Pada beberapa hasil penelitian dan jurnal penelitian menghasilkan simpulan bahwa tipe extrovert lebih sukses didalam mempelajari bahasa asing pada kompetensi Speaking. Sedangkan tipe introvert umumnya sukes dalam menguasai kompetensi Reading, Writing dan grammar. Sehingga tingkat keberhasilan peserta didik dalam menguasai Bahasa asing khususnya Bahasa inggris dapat ditentukan dengan gaya belajar berdasarkan tipe kepribadian peserta didik tersebut.
\end{abstract}

Kata Kunci : gaya belajar, tipe kepribadian, hasil belajar

\begin{abstract}
This paper is a study with literature studies from several journals, research results and reference books about the success of students in mastering English according to Learning Style in terms of the personality types of students. The method used is library research, where the author collects information from relevant studies. The personality type of students is focused on Extrovert and Introvert types, according to Myer and Briggs's statement that Extrovert and Introvert Personality types greatly influence student success in improving learning outcomes. From the reference books, information was obtained that the learning styles of Extrovert and Introverted personality types differ in the learning process of Foreign languages, especially English. In some research results and research journals it has been concluded that extrovert types are more successful in learning foreign languages in speaking competencies. While the introvert type is generally successful in mastering the competence of Reading, Writing and Grammar. So that the success rate of students in mastering foreign languages, especially English, can be determined by learning styles based on the personality types of these students.
\end{abstract}

\section{Keywords :learning style, personality type, learning outcomes}

\section{PENDAHULUAN}

Undang-undang Sisdiknas No. 20 tahun 2003, menyebutkan bahwapendidikan dimaknai sebagai usaha sadar dan terencana manusia untukmewujudkan proses pembelajaran yang efektif dan efisien dalam rangkamenggali dan mengembangkan potensi diri agar memiliki kekuatan spiritualkeagamaan, pengendalian diri, kecerdasan, akhlak mulia, serta keterampilanyang dibutuhkan masyarakat bangsa dan negara. Hal ini dapat tercapai jikaproses pembelajaran mampu mewujudkan tujuan pendidikan yangtelah digariskan oleh Undang-undang No. 20 tahun 2003 tentang SistemPendidikan Nasional, mengembangkanpotensi peseta didik agar menjadi manusia yang beriman dan bertakwa kepadaTuhan YME, berakhlak mulia, sehat, berilmu, cakap, kreatif, mandiri, danmenjadi warga negara 
yang demokratis serta bertanggung jawab.

Pendidikanmerupakan suatu upaya dalam mempersiapkan sumber daya manusia yangmemiliki keahlian dan keterampilan sesuai tuntutan pembangunan bangsa.Kualitas suatu bangsa sangat dipengaruhi oleh faktor pendidikan. Perwujudanmasyarakat berkualitas adalah tanggung jawab pendidikan, terutama dalammenyiapkan peserta didik sebagai subyek yang berperan secara aktif menampilkankeunggulan dan ketangguhan yang dimiliki, kreatif, mandiri serta profesionalpada bidangnya masing-masing. Upaya peningkatan mutu pendidikan dapattercapai secara optimal dengan pengembangan dan perbaikan terhadapkomponen pendidikan.

Upaya peningkatan mutu pendidikan di Indonesia dewasa ini terus menjadi topik kajian, dari kajian yang luas tentang pergantian kurikulum dari KTSP ke Kurikulum 2013, sampai kepada kajian yang ruang lingkupnya ada di dalam kelas, yaitu gaya belajar dan tipe kepribadianpeserta didik. Untuk mampu memahami dan menguasai pembelajaran, peserta didik yang memiliki latar belakang sosial dan kemampuan dasar yang berbeda, juga memiliki gaya atau style yang berbeda dalam usahanya untuk menguasai mata pelajaran dari gurunya. Secara teoretis, argumen tentang pentingnya memahami gaya belajar peserta didik untuk mencapai hasil belajar yang optimal sudah menjadi simpulan utama. Masing-masing individu, termasuk peserta didik, memiliki gaya belajar berbeda. Senada dengan pendapat Mann dan Sabatino (1985) bahwa individu dengan IQ yang sama, kecakapan yang sama, dan kemampuan memproses informasi yang sama, dalam banyak hal akan berbeda dari cara mereka menerima sesuatu, cara berfikir, menyelesaikan berbagai persoalan, dan mengingat sesuatu.

Gaya belajar peserta didik pada hakekatnya bukan hanya berbeda antara peserta didik yang satu dengan yang lainnya, tapi bisa juga berbeda antara mata pelajaran yang satu dengan mata pelajaran lainnya, bahkan gaya belajar bisa juga berbeda dikarenakan adanya perbedaan tipe kepribadian. Gaya belajar peserta didik pada mata pelajaran eksakta tentu berbeda dengan gaya belajar peserta didik pada mata pelajaran ilmu sosial. Penggunaan gaya belajar yang efektif terhadap suatu mata pelajaran atau pada materi tertentu pada akhirnya akan menghasilkan hasil belajar yang berkualitas bagi peserta didik sendiri.

Kenyataan dalam praktek pembelajaran,khususnya dikelas informasi dari peserta didik termasuk gaya belajarbelum dijadikan pertimbangan dalam pemilihan metoda, teknik, atau materi ajar pada hampir setiap tempat baik sekolah dasar, menengah, dan perguruan tinggi. Hal ini sesuai dengan apa yang dikemukakan oleh Hargove dan Poteet (1994:27) bahwa, "one of the most neglected aspect of diagnostic activity with students is the determination of their unique learning style." Hargove dan Poteet menempatkan aspek gaya belajar peserta didik menjadi bagian yang paling terlupakan untuk dipertimbangkan dalam proses pembelajaran. Davis (1989) percaya jika gaya belajar peserta didik dan gaya mengajar guru sejalan, maka banyak hal-hal positif yang bisa dicapai secara optimal seperti suasana belajar yang menyenangkan, motivasi belajar dan minat peserta didik meningkat, dan hasil belajar yang semakin meningkat. Sebaliknya, kata Davis (1989:45), "If teachers' teaching styles and students' learning styles do not match, there is usually disappointment and frustration on both sides.

Atas pertimbangan tersebut, maka gaya belajar bahasa Inggris peserta didik haruslah menjadi salah satu bagian pertimbangan yang penting bagi seorang guru. Ditambah lagi jika melihat masih rendahnya nilai Ujian Akhir Nasional (UAN) pada bidang studi Bahasa Inggris, hal ini dapat ditimbulkan oleh belum sesuainya gaya belajar peserta didik dengan gaya mengajar guru. Untuk itu, agar kualitas pembelajaran bahasa Inggris menjadi lebih baik, maka perlu diidentifikasi gaya belajar peserta didik. Hasil identifikasi ini akan bermanfaat sebagai pertimbangan bagi guru bahasa Inggris dalam pemilihan metoda, teknik atau materi ajar yang sesuai dengan kebutuhan dan gaya belajar peserta didik. Pada gilirannya, diharapkan, kualitas pembelajaran bahasa Inggris akan menjadi lebih baik.

\section{KAJIAN PUSTAKA}

\section{A. Tinjauan Tentang Gaya Belajar}

Banyak pendapat yang didefinisikan 
oleh beberapa ahli tentang gaya belajar. Menurut Fleming dan Mills (1992), gaya belajar merupakan kecenderungan peserta didik untuk mengadaptasi strategi tertentu dalam belajarnya sebagai bentuk tanggung jawabnya untuk mendapatkan satu pendekatan belajar yang sesuai dengan tuntutan belajar di kelas/sekolah maupun tuntutan dari mata pelajaran. Willing dalam Ardi (2007) mendefinisikan gaya belajar sebagai kebiasaan belajar yang disenangi oleh pelajar. Keefe (1979) memandang gaya belajar sebagai cara seseorang dalam menerima, berinteraksi, dan memandang lingkungannya. Dunn dan Griggs (1988) memandang gaya belajar sebagai karakter biologis bawaan. Definisi yang lebih menjurus pada gaya belajar bahasa dan yang dijadikan panduan pada tulisan ini dikemukakan oleh Oxford (2001:359) dimana gaya belajar didefinisikan sebagai pendekatan yang digunakan peserta didik dalam belajar bahasa baru atau mempelajari berbagai mata pelajaran.

Oxford (2001) mengkalisifikasikan gaya belajar bahasa kedalam empat bagian utama:

1. Sensory Preferences, Personality Types, Desired Degree of Generality, dan Biological Differences. Sensory preferences adalah cara belajar yang disenangi oleh seseorang yang terbagi kedalam empat bagian utama: visual, auditory, kinestetik, dan taktil. Peserta didik dengan gaya belajar visual lebih suka memproses informasi melalui simulasi visual. Kekuatan berada pada apa yang bisa mereka lihat. Bagi mereka belajar akan sulit dipahami tanpa dibantu oleh media yang dapat dilihat. Peserta didik dengan gaya belajar auditory lebih suka mendengar penjelasan. Kekuatan berada pada telinga. Peserta didik dengan gaya belajar kinestetik dan taktil, lebih suka dengan kegiatan yang menghendaki adanya gerakan seperti role play, drama, diskusi, atau debat. Mereka tidak suka belajar dengan hanya duduk dan mencatat.

2. Personality Type (tipe kepribadian), ) mengelompokkan peserta didik menjadi dua bagian: Ekstrovet dan Introvert. Peserta didik dengan gaya belajar ekstrovet lebih suka berinteraksi dengan orang lain untuk memperoleh pengetahuan. Mereka tidak malu bertanya kepada orang lain jika ada sesuatu yang tidak mereka ketahui. Sebaliknya peserta didik dengan gaya belajar introvert lebih suka menganalisa sendiri, bekerja sendiri. Mereka kelihatan lebih tertutup untuk berinteraksi dengan orang lain. Gaya belajar extrovert dan introvert memiliki keuntungan kelebihan tersendiri. Peserta didik dengan gaya belajar ekstrovet lebih cepat berhasil kalau tujuan belajar bahasa untuk komunikasi lisan, sebaliknya, peserta didik dengan gaya belajar introvet lebih unggul pada kemampuan membaca dan penguasaan ketatabahasaan mereka lebih baik.

3. Desired degree of generality, Oxford (2001) mengelompokkan peserta didik atas global dan analitik. Peserta didik dengan gaya belajar global lebih suka kegiatan yang bersifat komunikatif. Sebaliknya, peserta didik dengan gaya belajar analitik, lebih suka mempelajari struktur bahasa. Dari segi perbedaan biologis, kesenangan belajar peserta didik dikelompokkan atas waktu, tempat, dan perilaku ketika belajar. Berdasarkan waktu, sebagian peserta didik lebih suka belajar pagi, siang atau malam. Berdasarkan tempat, sebagian peserta didik lebih suka belajar di dalam kelas, atau di luar ruangan. Berdasarkan perilaku dalam belajar, sebagian peserta didik suka belajar sambil memakan makanan ringan dan sebagian yang lain lebih suka belajar sambil mendengarkan musik.

Beberapa istilah gaya belajar juga sudah didokumentasikan. Witkin (1949) mengunakan istilah field-independent dan field-dependent. Kolb (1976) mengunakan istilah convergers, divergers, assimilators, dan accommodators. Gregorc (1982) mengunakan istilah concrete sequential, abstract sequential, abstract random, dan concrete random. Pengelompokkan yang digunaka oleh Willing (1988) digunakan sebagai standar pengelompokkan gaya belajar dalam tulisan ini. Model penegelompokkan ini dipilih menjadi standar karena pengelompokkan yang dilakukan adalah gaya belajar yang digunakan dalam mempelajari bahasa Inggris. Willing mengelompokkan gaya belajar bahasa peserta didik kedalam empat 
bagian: concrete, analytical, authorityoriented, dan communicative.

Beberapa penelitian tentang gaya belajar bahasa telah dilakukan oleh beberapa peneliti. Reid (1987) mengidentifikasi gaya belajar 1388 mahapeserta didik asing dalam mempelajari bahasa Inggris sebagai bahasa kedua di Amerika Serikat. Hasil penelitiannya adalah, mahapeserta didik dari program study computer, teknik, dan kedokteran memiliki gaya belajar kinentetik dan auditory. Mahapeserta didik dari seluruh program studi kecuali yang berasal dari program studi Ilmu Pengetahuan Alam lebih suka belajar dalam kelompok. Beradasarkan asal negara, mahapeserta didik Korea lebih suka dengan gaya belajar visual, mahapeserta didik dari Cina dan Arab lebih suka dengan gaya belajar auditory, mahapeserta didik dari Thailand lebih suka dengan gaya belajar kinestetik. Penelitian lain dilakukan oleh Willing (1988) yang mengdentifikasi gaya belajar bahasa Inggris 517 imigran yang datang dari berbagai negara di Australia. Willing mengelompokkan empat gaya belajar bahasa Inggris imigran di Australia, yaitu: concrete, analytical, authority-oriented, dan communicative.

Kajian teoritis dan empiris menunjukkan bahwa peserta didik memiliki gaya belajar yang bervariasi. Disamping itu, juga disimpulkan bahwa hasil belajar yang optimal akan dicapai jika pendekatan mengajar, metoda mengajar, teknik mengajar, materi ajar mengakomodasi gaya belajar peserta didik. Untuk itu, informasi tentang gaya belajar peserta didik perlu diketahui.

\section{Gaya Belajar Bahasa dan Tipe Kepribadian \\ Kata kepribadian (personality)} berasal dari bahasa Latin yaitu kata kerja personare yang berartito sound through (mengucapkan lewat). Kata ini digunakan untuk melukiskan seorang aktor yang berbicara melalui topeng. Menurut Traxler sebagaimana dikuti oleh Lester D. Crow dalam bukunya yang berjudul educational psychology, kepribadian adalah keseluruhan tingkah laku individu dalam situasi sosial.Tingkah laku tersebut tidak hanya berupa tindakan-tindakan yang nyata, tetapi suasana batin yang ditimbulkan oleh situasi yang ditafsirkan oleh individu melalui introspeksi dirinya.

Sebagaimana diuraikan dalam Oxford (2001:359) bahwa salah satu type gaya belajar adalah tipe Kepribadian (Personality Type). Terdapat banyak pendapat yang berbeda-beda tentang tipe kepribadian. Namun, tipe kepribadian yang dimaksud tulisanini dibedakan menjadi dua yaitu tipe kepribadian extrovert dan tipe kepribadian introvert. Hal ini didukung oleh pendapatC. G. Yung sebagaimana dikutip F. Patty, bahwa manusia dengan tipe introvert menganggap dunia subjektiflah yang menjadi asas-asas pertimbangannya, ia tenggelam dalam dirinya sendiri. Manusia extrovert mempunyai minat pokok dunia luar dan menganggap dunia objektif itu sebagai nilai-nilai esensial dalam hidupnya. Serta pendapat yang disampaikan Myer and Briggs, yang menyatakan bahwa tipe Kepribadian Extrovert dan Introvert sangat berpengaruh terhadap keberhasilan peserta didik dalam meningkatkan hasil belajar.

Tipe extrovert dan introvert memiliki keunggulan dan kelemahan dalam proses pembelajaran. Dalam tulisan ini penulis sengaja membahas kedua tipe kepribadian (Personality Type) ini mengaitkannya dalam proses pembelajaran bahasa asing khususnya Bahasa Inggris.

\section{1) Tipe Extrovert}

Menurut Jung (dalam Hall dan Lindzey, 1978 : 125) bahwa extrovert adalah kepribadian yang lebih dipengaruhi oleh dunia objektif, orientasinya terutama tertuju ke luar. Pikiran, perasaan, serta tindakannya lebih banyak ditentukan oleh lingkungan. Eysenck juga mengatakan dalam teorinya, bahwa extrovert adalah satu ujung dari dimensi kepribadian introversi ekstroversi dengan karakteristik watak peramah, suka bergaul, ramah, suka menurutkan kata hati, dan suka mengambil resiko (Pervin, 1993 : 302).

Eysenck dan Eysenck (dalam Aiken, 1993 : 86) menggambarkan Extrovert sebagai berikut: yang khas dari extrovert adalah mudah bergaul, suka pesta, mempunyai banyak teman, membutuhkan teman untuk bicara, dan tidak suka membaca atau belajar sendirian, sangat membutuhkan kegembiraan, mengambil tantangan, sering menentang bahaya, berperilaku tanpa berpikir terlebih dahulu, 
dan biasanya suka menurutkan kata hatinya, gemar akan gurau-gurauan, selalu siap menjawab, dan biasanya suka akan perubahan, riang, tidak banyak pertimbangan (easy going), optimis, serta suka tertawa dan gembira, lebih suka untuk tetap bergerak dalam melakukan aktivitas, cenderung menjadi agresif dan cepat hilang kemarahannya, semua perasaannya tidak disimpan dibawah kontrol, dan tidak selalu dapat dipercaya (Aiken, 1993: 86).

Anak-anak extrovert lebih terbuka dan menyukai kegiatan-kegiatan berkelompok. Dunia ektrovert selalu dipengaruhi oleh dunia objektif, yaitu dunia diluar dirinya. Individu, bertipe ini berorientasi, keluar, pikiran, perasaan, serta tindakannya terutama ditentukan oleh lingkungannya, baik lingkungan sosial maupun non sosial. Dia bersikap positif terhadap masyarakat, hatinya terbuka, mudah bergaul, dan hubungan dengan individu lainnya lancar.

Pribadi dengan gaya extrovert biasanya tidak suka berdiam diri dan mengutamakan tindakan tanpa banyak merenungkan. Seringkali individu dengan tipe ini lebih dahulu bertindak baru memikirkan resiko yang akan menimpanya. Tipe ini sangat senang berbicara, menikmati berbagai variasi kegiatan, menyukai pengalaman dalam mempelajari sesuatu, serta suka berkenalan dan menjalin persahabatan.

Peserta didik dengan tipe extrovert menyukai interaksi dengan orang lain, dan lebih mempunyai orientasi pada tindakan. Mereka menemukan energi didalam berbagai hal pada orang-orang dan lebih suka belajar bersama-sama. Peserta didik tipe ini membutuhkan umpan balik dari guru dan dari tokoh yang dipercayainya. Untuk peserta didik dengan tipe ini guru perlu menciptakan satu kelas dimana peserta didik dengan gaya extrovert mempunyai beberapa kesempatan untuk berbicara dan berdiskusi, untuk menyajikan, mempresentasikan gagasan-gagasan mereka, dan untuk bergerak. Peserta didik dengan gaya belajar ekstrovet lebih cepat berhasil kalau tujuan belajar bahasa untuk komunikasi lisan (speaking). Mereka dengan cepat mampu mengucapkan apa yang mereka dengar dengan menambahkan varias-variasi kosa kata yang didapatnya.
Yang khas dari extrovert adalah mudah bergaul, suka pesta, mempunyai banyak teman, membutuhkan teman untuk bicara, dan tidak suka membaca atau belajar sendirian, sangat membutuhkan kegembiraan, mengambil tantangan, sering menentang bahaya, berperilaku tanpa berpikir terlebih dahulu, dan biasanya suka menurutkan kata hatinya, gemar akan gurau-gurauan, selalu siap menjawab, dan biasanya suka akan perubahan, riang, tidak banyak pertimbangan (easy going), optimis, serta suka tertawa dan gembira, lebih suka untuk tetap bergerak dalam melakukan aktivitas, cenderung menjadi agresif dan cepat hilang kemarahannya, semua perasaannya tidak disimpan dibawah kontrol, dan tidak selalu dapat dipercaya (Aiken, 1993 :86).

Secara umum, Ciri-ciri dari orang yang berkepribadian extrovert adalah sebagai berikut:

- Biasanya melakukan pekerjaan lebih baik jika ada hubungannya dengan orang lain.

- Kurang dapat mendisiplin diri sendiri.

- Extrovert lebih populer di sekolah dan biasanya mereka dipilih sebagai para pemimpin.

Dari paparan diatas, penulis menyimpulkan bahwa extrovert adalah suatu tipe kepribadian berdasar sikap jiwa terhadap dunianya, yang merupakan satu ujung dari dimensi kepribadian introversiekstroversi, yang dipengaruhi oleh dunia objektif, orientasinya terutama tertuju ke luar. Pikiran, perasaan, dan tindaknnya lebih banyak ditentukan oleh lingkungan. Peserta didik dengan gaya belajar extrovert lebih suka berinteraksi dengan orang lain untuk memperoleh pengetahuan. Mereka tidak malu bertanya kepada orang lain jika ada sesuatu yang tidak mereka ketahui. Pada umumnya peserta didik dengan type extrovert, dalam belajar bahasa, mereka lebih mudah menguasi kemampuan berbicara (speaking). Kemmapuan berbicara ini sebetulnya bersumber dari kemampuan sesorang dalam mendengarkan (listening) apa yang diucapkan oleh orang lain. Sehingga pada peserta didik jenis extrovert, kemampuan berbicara didukung oleh kemampuannya dalam mendengarkan (listening).

\section{2) Tipe introvert}


Menurut Eysenck, introvert adalah satu ujung dari dimensi kepribadian introversi - ekstroversi dengan karakteristik watak yang tenang, pendiam, suka menyendiri, suka termenung, dan menghindari resiko (Pervin, 1993 : 302). introvert adalah suatu tipe kepribadian berdasar sikap jiwa terhadap dunianya, yang merupakan satu ujung dari dimensi kepribadian introversi - extroversi, yang dipengaruhi oleh dunia subjektif, orientasinya terutama tertuju ke dalam.Introvert adalah kepribadian yang lebih dipengaruhi oleh dunia subjektif, orientasinya tertuju ke dalam. Peserta didik dengan gaya belajar introvert lebih suka menganalisa sendiri, bekerja sendiri. Mereka kelihatan lebih tertutup untuk berinteraksi dengan orang lain. Gaya belajar extrovertdan introvert memiliki keuntungan kelebihan tersendiri. peserta didik dengan gaya belajar introvert lebih unggul pada kemampuan membaca (reading) dan penguasaan ketatabahasaan (grammar) mereka lebih baik.

Seorang dengan gaya introvert cenderung menyimpan banyak rahasia tentang persoalan dirinya, juga banyak menjaga rahasia persoalan orang lain. Seseorang dengan gaya belajar introvert juga lebih memikirkan resiko yang akan terjadi sebelum mengambil tindakan. Dalam menyelesaikan pekerjaan, ia lebih suka melakukannya sendiri daripada berkelompok. Kesendirian baginya akan mendatangkan ide-ide, sumber dari energi, kepuasan, keselematan, dan untuk menikmati segala kejadian. Sesorang dengan gaya introvert menemukan energi pada gagasan-gagasan, konsep-konsep, dan abstraksi-abstraksi dan mereka harus berpikir dengan keras sebelum mereka mengambil resiko menjawab dihadapan orang lain.

Didalam lingkungan belajar, bila seluruh mahapeserta didik diberi kesempatan oleh guru untuk mengeluarkan pendapat, maka mahapeserta didik dengan gaya belajar introvert sering lambat dibandingkan dengan gaya extrovert. Mereka hanya akan mengeluarkan pendapat jika mereka memang telah yakin pengetahuan mereka dapat mengejutkan dengan tanggapan-tanggapan yang keras dan tak terduga. Orang introvert ingin memahami dunia secara mendalam. Guru perlu mendesain satu kelas yang mengijinkan ruang dan waktu tipe ini untuk berpikir dan belajar.

Yang khas dari introvert adalah pendiam, pemalu, mawas diri, gemar membaca, suka menyendiri dan menjaga jarak kecuali dengan teman yang sudah akrab, cenderung merencanakan lebih dahulu - melihat dahulu - sebelum melangkah, dan curiga, tidak suka kegembiraan, menjalani kehidupan seharihari dengan keseriusan, dan menyukai gaya hidup yang teratur dengan baik, menjaga perasaannya secara tertutup, jarang berperilaku agresif, tidak menghilangkan kemarahannya, dapat dipercaya, dalam beberapa hal pesimis, dan mempunyai nilai standar etika yang tinggi (Aiken, $1993: 87$ ).

Secara umum, orang yang memiliki kepribadian introvert ini umumnya memiliki ciri-ciri sebagai berikut:

- Lebih mudah diatur dan dididik.

- Lebih mendisiplin diri untuk belajar dengan baik.

- Lebih suka melakukan tugas yang detail, mempunyai kesanggupan untuk berkonsentrasi, dan bekerja dengan benda-benda daripada dengan orang.

- Introvert cenderung untuk menyendiri di kamar atau hanya mempunyai satu atau dua teman saja.

Dari paparan diatas, penulis menyimpulkan bahwa intovert adalah suatu tipe kepribadian berdasar sikap jiwa terhadap dunianya, yang merupakan satu ujung dari dimensi kepribadian extroversi-introversi, yang dipengaruhi oleh dunia subjektif, orientasinya terutama tertuju ke dalam.

\section{B. Tinjauan Tentang Hasil Belajar \\ 1. DefinisiBelajar}

Sebelum membicarakan pengertian hasil belajar, terlebih dahuluakan dikemukakan apa yang dimaksud dengan belajar. Parapakar pendidikan mengemukakan pengertian yang berbeda antara satu dengan yang lainnya, namun demikian selalu mengacu pada prinsip yang sama yaitu setiap orang yang melakukan proses belajar akan mengalami suatu perubahan dalam dirinya.

Beberapa ahli dalam dunia pendidikan memberikan definisi belajar sebagai berikut. Sntrock dan Yussendalam Sugihartono (2007:74) mengemukakan 
bahwa belajar merupakan sebagai perubahan yang relatif permanen karena adanya pengalaman. Sugihartono (2007: 74) mengemukakan bahwa belajar adalah suatu proses perubahan tingkahlaku sebagai hasil interaksi individu dengan lingkungannya dalam memenuhi kebutuhan hidupnya. Slameto(2010:3) mengemukakan belajar merupakan suatu proses perubahan tingkah laku sebagai hasil dari interaksi dengan lingkungannya dalam memenuhi kebutuhan hidupnya. Morgan dalam Purwanto (2002:84) mengemukakanbelajar adalah setiap perubahan yang relatif menetap dalam tingkah laku yang terjadi sebagai suatu hasil dari latihan atau pengalaman.

Daribeberapa pendapat tersebut, dapat disimpulkan definisi belajar. Belajar adalah suatu proses usaha yang dilakukan seseorang untuk memperoleh suatu perubahan tingkah laku yang barus ecara keseluruhan sebagai hasil pengalamannya sendiri dalam interaksi dengan lingkungannya.

\section{Faktor yang Mempengaruhi Belajar}

Hasi lbelajar setiap individu dipengaruhi oleh belajar peserta didik. Muhabbibin Syah (2003:144) menyebutkan tiga faktor yang mempengaruhi belajar peserta didik yaitu faktor internal, eksternal dan pendekatan belajar.

a . Faktor dari Dalam

yaitu faktor-faktoryangdapatmempengaruhi belajaryang berasal dari peserta didik belajar. Faktor dari dalam (internal) meliputi dua aspek, fisiologi dan psikologis.

1) Fisiologi, faktor ini meliputi kondisi jasmaniah secara umum dan kondisi pancaindra.

2) Kondisi psikologis, faktor ini meliputi kecerdasan, bakat, minat, motivasi, emosi dan kemampuan kognitif.

b. Faktor dari Luar

yaitu faktor-faktor yang berasal dari luar peserta didik yang mempengaruhi proses dan hasil belajar. Faktor-faktor ini meliputi lingkungan sosial dan lingkungan non sosial.

1) Lingkungan sosial yang dimaksud adalah manusia atau sesama manusia, baik manusia itu ada (kehadirannya) ataupun tidak langsung hadir. Dalam lingkungan sosial yang mempengaruhi belajar peserta didik inidapat dibedakan menjadi tiga yaitu rumah, sekolah dan masyarakat.

2) Lingkungan nonsosial meliputi keadaan udara, waktu belajar, cuaca, lokasi gedung sekolah dan alat-alat pembelajaran.

c. Faktor pendekatan belajar (approach tolearning) yaitu jenisupaya belajar yang meliputi strategi, model, metode dan gaya yang digunakan peserta didik untuk melakukan kegiatan pembelajaran materi-materi pelajaran.

Dengan demikian guru harus memperhatikan perbedaan individu dalam memberikan pelajaran kepada mereka, supaya dapat menangani peserta didik sesuai dengan kondisi yaitu untuk menunjang keberhasilan belajar. Hal tersebut dikarenakan faktor-faktor yang mempengaruhi belajar peserta didik, satu dengan yang lainnya berbeda. Salah satu yang mempengaruhi belajar adalah faktor pendekatan belajar(approachto learning), yang didalamnya terdapat Gaya Belajar.

\section{Hasil Belajar}

Hasil belajar adalah terjadinya perubahan tingkah laku pada seseorang yang belajar, misalnya dari tidak tahu menjadi tahu, dari tidak mengerti menjadi mengerti. Tingkah laku memiliki unsur subjektif dan unsur motoris. Unsur subjektif adalah unsur rohaniah, sedangkan unsur motoris adalah unsur jasmaniah. Tingkah laku manusia terdiri dari sejumlah aspek sedangkan hasil belajar akan tampak pada setiap perubahan pada aspek-aspek tersebut. Jika seseorang telah melakukan perbuatan belajar maka akan terlihat terjadinya perubahan dalam salah satu atau beberapa aspek-aspek tersebut. Adapun aspek-aspek itu adalah: pengetahuan, pengertian, kebiasaan, keterampilan, apresiasi, emosional, hubungan sosial, jasmani, etis atau budi pekerti, dan sikap (Hamalik : 2003).

Sudjana (2005: 5) menyatakan bahwa hasil belajar peserta didik pada hakikatnya adalah perubahan tingkah laku dan sebagai umpan balik dalam upaya memperbaikiproses belajarmengajar. Tingkah laku sebagai hasilbelajar dalam pengertianluas mencakup bidangkognitif, afektifdan psikomotorik.

Arikunto (2006 : 20) mendefinisikan hasil belajar adalah tingkat capaian penguasaan 
kemampuan yang diperoleh peserta didik setelah mengikuti kegiatan belajar mengajar. Selanjutnya, Sardima, menyatakan bahwa hasil belajar adalah capain kemampuan yang diperoleh oleh peserta didik berupa peningkatan pengetahuan, pemahaman konsep, penguasaan keterampilan dan pembentukan sikap.

Ada 3 bentuk hasil belajar (Daryanto : 1999), yaitu:

1. Hasil belajar kognitif, terdiri dari: pengamatan, tanggapan dan fantasi,ingatan.

2. Hasil belajar afektif, terdiri dari perasaan, emosi, dan suasana hati.

3. Hasil belajar psikomotorik adalah perbuatan melakukan aktifitas atau kegiatan belajar.

Tirtonegoro

(2001:43)

mengemukakan hasil belajar adalah penilaian hasil usaha kegiatan belajaryang dinyatakan dalam bentuk simbol, angka, huruf maupun kalimat yang dapat mencerminkan hasil yang sudah dicapai oleh setiap peserta didik dalam periode tertentu. Djamarah (1996:23) mengungkapkan hasil belajar adalah hasil yang diperoleh berupa kesan-kesanyang mengakibatkan perubahan dalam diri individu sebagai hasil dari aktivitas dalam belajar.

Berdasarkan pengertian hasil belajar di atas, disimpulkan bahwa hasil belajar adalah kemampuan-kemampuan yang dimiliki peserta didik setelah menerima pengalaman belajarnya. Kemampuankemampuan tersebut mencakup aspek kognitif, afektif, dan psikomotorik. Hasil belajar dapat dilihat melalui kegiatan evaluasi yang bertujuan untuk mendapatkan data pembuktian yang akan menunjukkan tingkat kemampuan peserta didik dalam mencapai tujuan pembelajaran yang dinilai dalam periode tertentu.

\section{Gaya Belajar Bahasa Inggris Berdasarkan Tipe Kepribadian}

Dalam uraian sebelumnya sudah dijelaskan kajian tentang gaya belajar bahasa berdasarkan tipe kepribadian dengan prestasi atau hasil belajarnya. Ada beberapa kecenderungan yang terlihat pada pelajar bahasa ketika mereka ingin mempelajari bahasa asing atau bahasa kedua. Aspek tersebut adalah cara belajar yang terbuka dan tertutup terkait dengan kepribadian introvert dan extrovert.

Aspek terbuka dan tertutup dari pelajar bahasa di dalam kelasterlihat dari cara belajar yang memiliki orientasi secara tertutup, atau sejauh mana orang tersebut perlu mencapai keputusan atau kejelasan. Cara ini sangat erat kaitannya dengan toleransi ambiguitas dan juga terkait dengan fleksibilitas dalam belajar dan cara untuk menyelesaikan masalah. Peserta didikyang berorientasi pada cara yang tertutup yaitu berusaha dengan keras, terorganisir, dan terencana. Mereka cenderung menyukai tata bahasa yang harus dinyatakan dengan jelas. Kegiatan spontan tidak diminati tipe peserta didik ini karena lebih memilih sesuatu yang harus dipersiapkan terlebih dahulu. Sementara cara belajar yang terbuka memilih cara belajar yang jauh dari serius seperti anggapan bahwa permainan bukanlah suatu tugas. Keterbukaan dapat bermanfaat dalam beberapa situasi, terutama hal yang membutuhkan fleksibilitas dan pengembangan kefasihan, tapi dapat merugikan dalam situasi yang lain, seperti pengaturan ruang kelas yang terstruktur dan tradisional.

Cara Untuk Memotivasi Pelajar Bahasa:

- Memberikan pujian kepada peserta didik yang melakukan sesuatu dengan baik meskipun hal itu tidak begitu berarti.

- Kurangilah kecaman atau kritik yang dapat mematikan motivasi peserta didik.

- Menciptakan persaingan yang sehat di antara peserta didik.

- Menciptakan kerjasama antara peserta didik.

- Berikan umpan balik kepada peserta didik atas hasil pekerjaannya.

Carrol (1962: 128-30) telah mengidentifikasi 4 kemampuan yang independen yang membentuk bakat belajar Bahasa kedua, yaitu :

1. Kemampuan mengkode fonetik artinya kemampuan untuk "mengkode" bahan fonetik auditoris sedemikian rupa sehingga hal ini bisa di ketahui, diidentifikasi, dan diingat sedikit lebih lama dari beberapa detik.

2. Kepekaan gramatis artinya kemampuan untuk mengenal fungsi gramatis dari kata-kata dalam konteks kalimat.

3. Kemampuan belajar bahasa secara induktif yang artinya kemampuan 
untuk menarik kesimpulan bentukbentuk, kaidah-kaidah, dan pola-pola linguistik dari isi linguistik baru itu sendiri dan sedikit pengawasan dan bimbingan.

4. Kemampuan mengingat di luar kepala adalah kemampuan untuk mempelajari sejumlah besar asosiasi dalam waktu yang relatif pendek

\section{METODE}

Metode yang digunakan dalam penelitian ini adalah studi kepustakaan, dimana penulis mengumpulkan informasi dari penelitian - penelitian yang relevan. Beberapa informasi dan data juga penulis ambil dari beberapa buku dan jurnal yang ada kaitannya dengan topik penelitian.

\section{HASIL DAN DISKUSI}

Pada beberapa hasil penelitian dan jurnal penelitian menghasilkan kesimpulan bahwa type extrovertlebih sukses didalam mempelajari bahasa asing pada kompetensi Speaking. Seperti penelitian yang dilakukan oleh Gass and Selinker (2008) menyatakan bahwa extrovert lebih baik dari introvert karena extrovert lebih banyak bicara dan ingin terlibat secara langsung dalam aktivitas sosial. Tetapi Ehrman (2008) menyatakan bahwa peserta didik yang introvert bertentangan dengan penelitian sebelumnya seperti juga Troike (2012) menemukan bahwa pemelajar yang berhasil menguasai bahasa dengan baik adalah pemelajar yang introvert karena ternyata mereka memiliki konsentrasi yang lebih dalam pemelajaran di kelas.

Pada beberapa penilitian lainnya menunjukkan bahwa tipe introvert umumnya sukses dalam menguasai kompetensi Reading, Writing dan grammar. Pada penilitian yang dilakukan oleh Erton (2010) pada mahasiswa tahun pertama di lima fakultas di Bilken University, ditemukan bahwa tidak ada hubungan yang signifikan, hanya hubungan statitik yang lemah antara personality trait (introversionextroversion) terhadap keberhasilan peserta didik dalam mempelajari bahasa asing. Beliau dalam penelitian juga menambahkan bahwa setiap kelompok group kepribadian memiliki gaya belajar yang berbeda-beda. Gaya belajar ini yang justru memberikan pengaruh yang cukup signifikan terhadap kerberhasilan peserta didik dalam menguasai bahasa asing.

\section{PENUTUP}

Keberhasilan pembelajaran bahasa asing, khususnya Bahasa Inggris didalam kelas bukan hanya dipengaruhi oleh faktor kompetensi guru dalam menyampaikan materi dan model pembelajaran, tetapi juga faktor lain yang mempegaruhi peserta didik dalam menyerap materi pembelajaran. Faktor tersebut antara lain motivasi, gaya belajar, tahap perkembangan dan faktor tipe kepribadian peserta didik.

Tugas pendidik adalah memahami akan berbagai faktor pendukung pendidikan tersebut. Peserta didik sebagai objek dari pendidikan sangat urgen untuk diperhatikan dari berbagai faktor tersebut. Salah satu faktor yang harus diperhatikan sebagaimana diungkapkan diawal adalah faktor tahap perkembangan dari peserta didik tersebut. Diantara perkembangan perserta didik tersebut adalah bagaimana individu dan karakteristiknya.

Setiap peserta didik memiliki cara yang berbeda untuk beradaptasi dan memahami petunjuk khususnya dalam pembelajaran bahasa. Seperti yang kita ketahui bahwa setiap individu itu memiliki keunikan masing - masing. Keunikan yang ada pada masing-masing individu yang akan membedakan cara berpikir, berperasaan, dan bertindak. Tidak ada individu yang sama dengan individu lain, sekalipun kembar identik. Pada dasarnya, keunikan yang dimiliki individu mengacu kepada perbedaan. Setiap perbedaan - perbedaan itu menjadikan individu tersebut mencapai hasil yang berbeda. Dalam pembelajaran, khususnya pembelajaran bahasa, setiap individu memiliki cara masing - masing untuk mencapai hasil yang maksimal.

Sebagaimana diuraikan dalam hasil penelitian, dalam pembelajaran bahasa asing (Bahasa Inggris), tipe kepribadian anak extrovert dananak yang introvert juga dapat menerima materi pembelajaran dengan baik dan sewaktu-waktu dapat menggunakannya dengan benar.

\section{DAFTAR PUSTAKA}

Ardi, Havid. 2010. Profil Gaya Belajar Bahasa Inggris SMAN 7 Padang; 
Jurnal Bahasa dan Seni: FBSS: UNP Padang.

Arikunto, Suharsimi, 2006,

ProsedurPenelitianSuatuPendekatan Praktik, Cet. XIII,Jakarta: PT RinekaCipta, h. 20.

Carroll, J B. 1993. Human Cognitive Abilities. Cambridge: Cambridge University Press

Daryanto, 1999, EvaluasiPendidikan, Cet. I, Jakarta: RinekaCipta.

Debora, Irene. 2013. Kepribadian Extrovert Dan Introvert Dalam Pembelajaran Bahasa Inggris, https://deborairene16.wordpress.com/ 2013/06/03/kepribadian-extrovertdan-introvert/ diakses pada 14 Maret 2015

Djamarah,Saiful

Bahri.2002.PsikologiBelajar,Jakarta:Rinek aCipta

Drummond, I.A., 1989. Assessing Children's Learning: USA, David Fulton

Dunn, Rita Stafford., Griggs, Shirley A. 1988. Learning styles: quiet revolution in American secondary schools. National Association of Secondary School Principals,

Erton, Ismail, 2010. Relations Between Personality Traits, Language Learning Styles And Success In Foreign Language Achievement. H.U Journal of Education, 38:115-126.

Gass, Susan M., Selinker, Larry., 2008. Second Language Acquisition: An Introductory Course (3rd Edition). New York: Routledge/Taylor Francis

Hamalik, Oemar, Proses BelajarMengajar, Jakarta: BumiAksara, 2003 h. 30.

Hargrove, L.J., \& Poteet, J.A. 1984. Assessment in Special Education: The Education Evaluation. Englewood Cliffs, NJ: Prentice Hall.
Mann, Lester., Sabatino, David,A. 1985. Foundations of Cognitive Process in Remedial and Special Education. USA: Aspen Pub.

Muhibbin Syah, 1999. Psikologi Pendidikan Dengan Pendekatan Baru, Bandung: PT Remaja Rosdakarya

Oxford, R.L., 1990. Language Learning Strategies: What Every Teacher Should Know. Boston: Heinle \& Heinle.

Purwanto,Ngalim,2006.

PsikologiPendidikan,Bandung:RemajaRos dakarya

Slameto, 2003. Belajar dan Faktor-Faktor yang

Mempengaruhinya.Jakarta:RinekaCipta.

Sudjana, Nana. 2005. Penilaian hasil proses belajar mengajar. Bandung: Rosda

Sudjana, Nana, dkk.,2007, PenelitiandanPenilaianPendidikan, Bandung: SinarBaruAlgensindo, hal. 110.

Syah, Muhibbin, 2003, PsikologiBelajar, Jakarta: RajagrafindoPersada.

Tirtonegoro, Suratinah. 2001. Penelitian Hasil Belajar. Surabaya: Usaha Nasional.

Troike, Muriel Saville., 2012. Introducing Second Language Acquisition: Cambridge: Cambridge University Press 